\title{
Changing Trends in Cultivation Practices and Adoption of Climate Adaptive Farming in Eastern Nepal
}

\author{
Bed Mani Dahal ${ }^{1}$, Nani Raut ${ }^{1}$, Smriti Gurung ${ }^{1}$, Chhatra Mani Sharma ${ }^{1}$, Rabindra Kayastha ${ }^{1}$, Ahuti Shrestha ${ }^{1} \&$ \\ Bibhu Gautam ${ }^{1}$ \\ ${ }^{1}$ School of Science, Kathmandu University, PO Box 6250, Kathmandu, Nepal \\ Correspondence: Bed Mani Dahal, Department of Environmental Science and Engineering, School of Science, \\ Kathmandu University, Nepal. Tel: 977-011-661-399. E-mail: bedmani@ku.edu.np
}

Received: February 3, 2018 Accepted: February 20, 2018 Online Published: May 9, 2018

doi:10.5539/sar.v7n3p52

URL: https://doi.org/10.5539/sar.v7n3p52

\begin{abstract}
Climate change impacts are likely to affect the agricultural production leading to further food insecurity. In this context, the trend of cereal production with climate variables was studied in order to understand the linkages between climate change and crop productivity. The study was conducted in three districts of Sagarmatha zone, namely Solukhumbu (mountain region), Okhaldhunga (hill region) and Saptari (Terai region) representing three ecological zones in Nepal. A household survey (295 households), focus group discussions and key informant interviews were used to collect data on the history of the cultivation systems, varieties of crop grown, trends on crop yield, and adaptation to climate change. Results showed farmers' introduction of high yielding varieties of crops and vegetables due to economic benefit, while traditional varieties are no longer cultivated. The infestation of pest attack is increasingly seen since two decades, while few pests were reported to be disappeared. Although majority of farmers in Saptari and Okhaldhunga districts used pesticides as per the prescribed doses, pesticide use is still random in Solukhumbu district. The multiple comparisons of means showed that there is a significant difference in the average production of rice and maize since 30 years until recently $(p<0.05)$ in these three districts. The average production of rice, maize and wheat increased with decreasing average annual temperature and rainfall in Saptari district since 30 years. In contrast, in Okhaldhunga and Solukhumbu districts, the average production of three cereal crops increased with increasing average annual temperature and rainfall. With the late arrival of the monsoon, farmers have adopted coping strategies particularly for rice cultivation through occasional shift in crop planting dates and selection of shorter duration crop varieties that can be harvested early.
\end{abstract}

Keywords: agriculture, climate change, terai, hill, mountain, crop productivity, and adaptation

\section{Introduction}

South Asian countries have a number of common features such as high human-to-land area ratio, a high share of agriculture making up gross domestic product (GDP), weak infrastructure and a high proportion of population below the poverty line. The per capita arable land area in the region is declining with increasing population. The average per capita cropland (ha/person) for the region was 0.38 in 1960, and is projected to be about 0.10 in 2025, and 0.093 by 2050 (Lal, 2011). The necessity of increasing food production due to rapid population growth, especially during the $20^{\text {th }}$ century, was achieved through the 'Green Revolution' by growing input-responsive and improved varieties with increased application of fertilizers and irrigation (Lal, 2011). This led to a remarkable increase in yield in Asia in the late 1960s, and global food production increased three-fold between 1961 and 2006 (FAO, 2008).

However, increased agricultural production is an ever-growing requirement to fulfil the food demand and poverty reduction in Nepal (Pyakuryal et al., 2005), as the traditional farming practices are unable to fulfil the increasing food demand with most of the districts in a food deficit situation (CBS, 2003). Although agricultural land expansion is an option for increasing food production, there is little scope left for expansion of arable land (Pingali \& Rosegrant, 2001). Hence intensification of the already cultivated lands is the only viable option (Dahal et al., 2009). The areas with access to road, market, inputs and institutional development located close to the semi- and peri-urban areas are the most potential sites for agricultural intensification (Dahal et al., 2008). 
Natural frequent occurrences of loss of fertile soil, nutrients, natural disasters such as Glacier Lake Outburst Flood (GLOF) in mountain regions; landslides in the Hills and floods in Terai are accelerated by changing weather patterns (Regmi \& Adhikari, 2007). As a result of variations in weather patterns, the type, frequency and intensity of extreme events such as droughts, heavy precipitation and flood events are also expected to rise with relatively small average temperature increases. Changes in rainfall pattern are likely to lead to severe water shortages and/or flooding. Under such circumstances, Nepal, being one of the poorest countries, adaptation to climate change entails taking adequate measures to reduce the negative effects of climate change by making the appropriate adjustments and changes (MOE, 2010). Accordingly, the Government of Nepal has recently initiated different adaptation strategies to combat the adverse impacts of climate change at the national as well as local levels.

Although, the government has just initiated a planned climate change adaptation pilot programme, communities in this region have been responding autonomously to climate change stresses (Tiwari et al., 2014). These involve changes in cropping practices and technologies, diversification of livelihood systems, accessing financial resources, such as, micro-insurance and micro-credit, migration, off farm activities, and water conservation practices. As a coping mechanism for agricultural production in a changing environment, farmers are shifting their agricultural calendars (Paudel et al., 2014).

The Agriculture Prospective Plan (APP) of 1995 has set per capita targets for food production of $245 \mathrm{~kg}, 380 \mathrm{~kg}$ and $482 \mathrm{~kg}$ for the mountain, hill and Terai regions, respectively, which were to be met by 2014/15 (APP, 1995). The APP strategy is to accelerate the agricultural growth rate by transforming the subsistence-based agriculture into a commercial one through diversification and production of high-value commodities in agriculture. Despite this, the performance of the agricultural sector has fallen short of the targets. Production of the country's major cereal crops has remained stagnant for the past few decades (Bajracharya \& Sherchan, 2009). This is partly because of the deficiency in availability of inputs such as improved and good quality seeds, affordable chemical fertilizers, and incentives for farmers to plant high value commodities. Moreover, climate change effects are likely to adversely impact the agricultural production leading to further food insecurity (Jat et al., 2016). Therefore, there is a need to assess the trend of cereal production over the past few decades with regard to climatic variables in order to develop adaptive strategies for cereal production linked with climate change. Thus we aimed to assess the production trend over a period of three decades in three districts of Nepal representing each ecological region; and to understand the linkages between climate variables and crop productivity. We also aimed to assess how the local communities are coping with changing climate in crop production process.

\section{Materials and Methods}

\subsection{Study Area}

The study was conducted in the three districts of Sagarmatha zone, namely Solukhumbu (mountain region), Okhaldhunga (hill region) and Saptari (terai region) representing three ecological zones (Figure 1). Sagarmatha zone was selected based on the zone's climate change vulnerability due to the presence of glacial lakes, snow-fed rivers, landslides, flash floods, flood and drought. All the selected districts of the zone have incurred higher economic losses by natural disasters during 1993 to 1994 and 2000-2005 (DWIDP, 2014). The Solukhumbu district experiences water scarcity during winter and significant reduction in irrigation water due to the variability of the summer monsoon (Bartlett et al., 2010). The news related to climate change in the study areas has also been highlighted in national newspapers. Some examples include news that people in the mountains are unaware of the changing climate (Published in Republica, 29 August 2014). Hilly district like Okhaldhunga has experienced growing numbers of landslides and flash flooding cases where as Terai districts including Saptari are in higher risk of being flooded due to increased water level due to glacial lake outbursts in mountains (The Himalayan Times, 2011). One VDC in each district, Tingla (Solukhumbu district), Prapcha (Okhaldhunga district) and Hanumannagar (Saptari district) was selected for the study. The VDCs were selected based on intensity of agriculture, climate change vulnerability, and accessibility.

\subsection{Survey Methods}

Both primary and secondary data were collected through field visits and rigorous literature survey. Household survey, focus group discussions and key informant interviews were used to collect primary information on history of cultivation systems, varieties of crop grown, agro-inputs use, trends on crop yield, linkage between agricultural productivity with climate change, and perception and adaptation of communities to climate change. The survey was done between April and September 2015. 
Purposive random sampling was done to select the households for survey in order to include all nine wards of each VDC. Out of the total households in the VDCs (CBS, 2011), at least $10 \%$ of the households from each VDC were selected for the questionnaire survey. A total of 295 households ( 95 from Hanumannagar and 100 each from Prapcha and Tingla VDCs) were included in the survey. A structured questionnaire that comprised both close and open-ended questions was developed and pretested with respondents of similar biophysical and socioeconomic conditions to confirm rightness of the questions. Two local enumerators were involved in the survey. The local enumerators were well trained before the start-up of the survey. The interview was conducted with the head of the households who are usually a male member and usually a decision maker in the family.

Focus group discussions consisting of 20-25 participants was carried out in all the study sites. The participants of group discussions were selected representing each ward including women and marginalized people such as ethnic minorities. The participants were mainly farmers and permanent residents of the VDCs. Each discussion lasted for 3 to 4 hours. The discussions mainly focused on the different aspects such as agricultural activities, trend of agro-cultivation, agro-inputs, crop productivity and climatic effects on agro-products. Similarly, the perception on change in crop production and climate change were also documented.

Key informant interviews were also carried out in each VDC. A total of ten key informants, three to four key informants from each studied VDCs, were identified during the focus group discussions and interviewed separately. Key informant interviews were mainly focused on in-depth data on the cultivation dates irrigation, use of fertilizers, crop production, weather variables, etc. Climate change adaptation measures adopted by farmers were also documented during the field visits.

The meteorological data for three decades were obtained from the Department of Hydrology and Meteorology to relate the trend of agricultural activities with climate change.

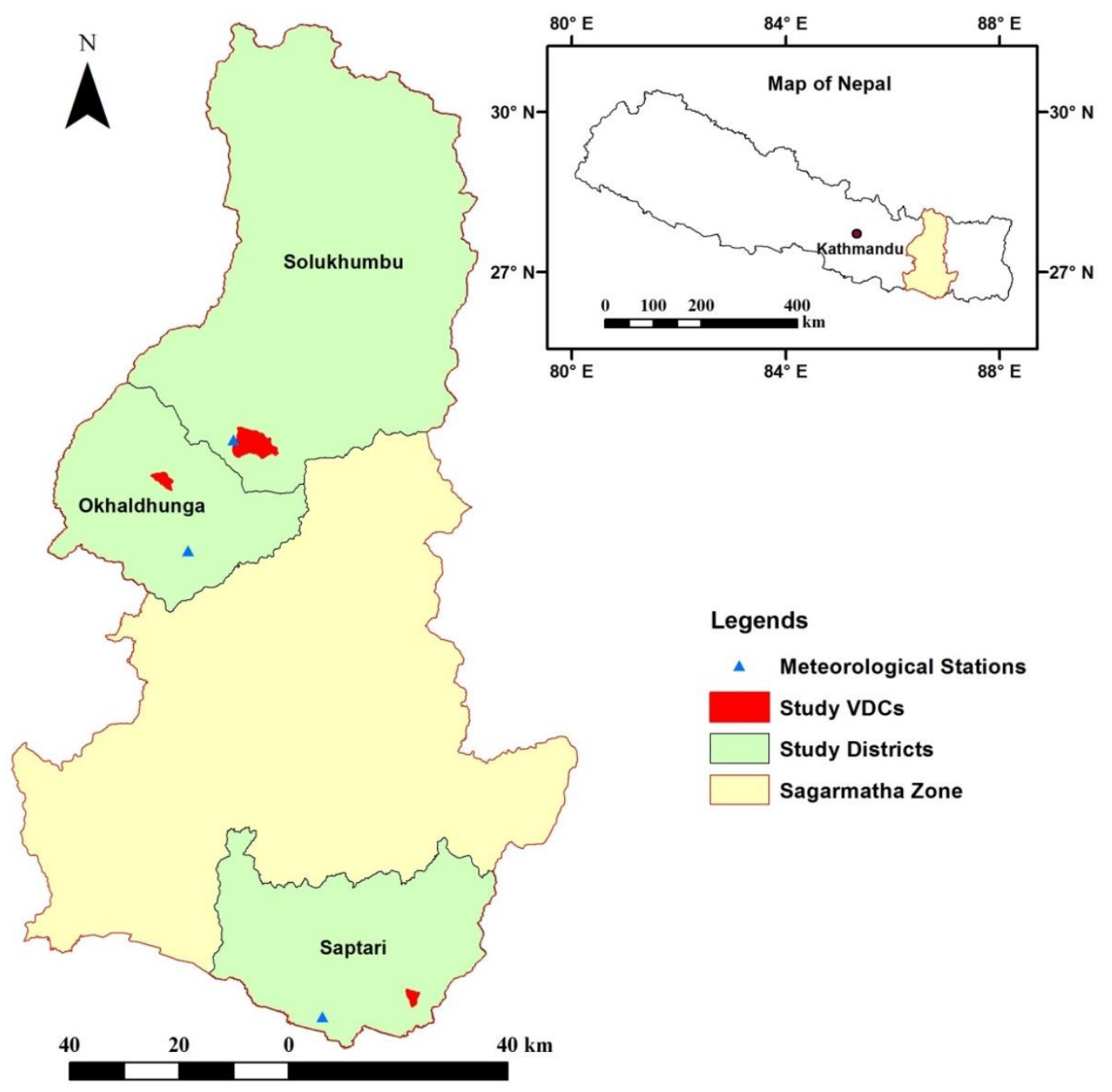

Figure 1. Location of the study area 


\subsection{Data Analysis}

Data collected from questionnaire survey were coded and computed in MS-Excel and were processed and analysed using SPSS (version 19.0). Rates of changes in cereal yield (mainly for rice, wheat and maize) were analysed for three reference years, 1984, 1994 and 2014. These data were analysed using descriptive statistics (Frequency distribution, mean, standard deviation, percentage of frequency distribution), correlation analysis, and multiple comparisons of means. Similarly, the meteorological data obtained from the Department of Hydrology and Meteorology were computed in MS-Excel and analysed for calculation of mean, maximum, minimum for temperature, rainfall, and relative humidity.

\section{Results}

\subsection{Historical and Recent Changes in Cultivation Practices}

\subsubsection{Changes in Crops Grown}

According to focus group discussions and key informant interviews, farmers of Saptari district reported rice, maize, and wheat as the major crops, but they also grow mustard, pulses, flaxseed and vegetables. About 10 to 12 years ago, farmers grew Aghani varieties of rice such as Jaspal, Prakiti, and Basmati which are not cultivated anymore. The overall trade of rice has increased, as it is the main crop in the area. Farmers in Saptari also reported that mustard cultivation started 15 years ahead of wheat cultivation when the latter was introduced from India for the religious purposes. The main vegetables that farmers have newly introduced are cauliflower, tomato and green peas, while potato was introduced around a decade ago. Farmers generally believed that vegetable farming gave better economic benefits compared to cereal crop cultivation.

The major crops grown in Okhaldhunga district are rice, maize, millet, wheat, buckwheat, mustard and vegetables. Rice cultivation started as early as one hundred years ago when varieties such as Mansuli and Junge were cultivated; and 50 years ago, other varieties such as Rambilash and Atte started to be cultivated. Current varieties of rice that are being cultivated in Okhaldhunga are Taichung, Radha, and others. Wheat was introduced much later after a major drought occurrence in 1971, and its cultivation has been widely practised since 1975 . The common traditional varieties of maize that are cultivated widely are SetoPudko and Paheli while high yielding varieties are grown in relatively small areas. Potato was introduced in 1969 after the region experienced a famine. During the focus group discussions, farmers reported that there was an increase in the production of rice and potatoes due to improved access to irrigation facilities and introduction of high yielding varieties of crops. In contrast, millet cultivation has declined due to the lack of market value. The main vegetable crops that farmers have recently introduced are tomato and chilli. However, during the key informants interview, it was revealed that increased pest infestation have resulted decline in chilli production. Among the pulses also, there is a decline in the cultivation of black lentil and Masyang which were common during the 1960s.

The major crops grown in Solukhumbu district are maize, millet, wheat, buckwheat, and barley while few farmers also practise mustard and rice cultivation. The traditional varieties of maize namely, Pahelo and Seto are being cultivated in different times of the year for the last 100 years, although high yielding varieties are also cultivated nowadays. For the last 10 years Deuki and Ganesh varieties of maize have also been grown. The cultivation of millet has declined, as according to farmers it is not economically profitable; and it is grown mainly as animal feeds in recent years. Meanwhile, millet is also grown in upland areas in recent years due to warmer temperatures. Wheat was introduced later than the other crops. The first variety cultivated was Dolakhe followed by a high yielding variety RR-21. Interestingly, the Dolakhe variety was not given to children due to fear of diarrhoea. Although, potato is considered as a vegetable, it is one of the main crops being cultivated in most of the places in Solukhumbu district for a long time. Farmers have reduced the cultivation of barley and buckwheat due to lack of manpower, while cultivation of chilli is growing. Farmers reported the cause for increase in chilli cultivation as it requires less labour compared to major cereal crops.

\subsubsection{Changes in Irrigation Facility}

The local farmers have been irrigating their fields mainly by means of canals from rivers or from streams and springs. The construction of irrigation canals in Saptari district has been expanded with support from district development committee for adopting a wider variety of crops. The primary source of water for irrigation in Saptari district is irrigation canal; however, a few farmers also have deep bore wells to draw water. Likewise, irrigation by means of stream and spring canal (kulo) is a fairly recent practice in Okhaldhunga district. Nonetheless, a majority of respondents from Saptari (63\% of the total respondents) and Solukhumbu (93\% of the total respondents) reported they do not have irrigation facility. On the other hand, a majority of the respondents $(65 \%)$ from Okhaldhunga reported that they have access to irrigation facilities. 


\subsubsection{Crop Production}

The trend of cultivation and rate of production of different cereal crops (rice, maize and wheat) between the present as compared to 2004, 1994, 1984 are presented in table 1. The average yields of rice increased over the past 30 years by $37 \%, 22 \%$ and $19 \%$ in Saptari, Okhaldhunga and Solukhumbu districts, respectively. The average yields of rice during 1984 were $487 \mathrm{~kg} / \mathrm{ha}, 495 \mathrm{~kg} / \mathrm{ha}$ and $403 \mathrm{~kg} / \mathrm{ha}$, and during 2014 were $2599 \mathrm{~kg} / \mathrm{ha}$, $1116 \mathrm{~kg} / \mathrm{ha}$ and $1077 \mathrm{~kg} / \mathrm{ha}$ in Saptari, Okhaldhunga and Solukhumbu, respectively. The average yields of maize have also increased during the past 30 years by $60 \%, 78 \%$ and $3 \%$ in Saptari, Okhaldhunga and Solukhumbu districts, respectively. The average yields of maize during 1984 were $189 \mathrm{~kg} / \mathrm{ha}, 157 \mathrm{~kg} / \mathrm{ha}$ and $281 \mathrm{~kg} / \mathrm{ha}$, and during 2014 were $1496 \mathrm{~kg} / \mathrm{ha}, 371 \mathrm{~kg} / \mathrm{ha}$ and $426 \mathrm{~kg} / \mathrm{ha}$ in Saptari, Okhaldhunga and Solukhumbu, respectively. The average yields of wheat, has likewise, increased during the past 30 years by $95 \%, 71 \%$ and $50 \%$ in Saptari, Okhaldhunga and Solukhumbu districts, respectively. The average yields of wheat during 1984 were $12 \mathrm{~kg} / \mathrm{ha}$, $19 \mathrm{~kg} / \mathrm{ha}$ and $80 \mathrm{~kg} / \mathrm{ha}$, and during 2014 were $157 \mathrm{~kg} / \mathrm{ha}, 66 \mathrm{~kg} / \mathrm{ha}$ and $235 \mathrm{~kg} / \mathrm{ha}$ in Saptari, Okhaldhunga and Solukhumbu respectively. Farmers reported the increase in production of rice, maize and wheat was mainly due to high yielding varieties and that they could irrigate their agricultural lands easily. This study was carried out in eastern region of Nepal, which receives more rainfall and agro-inputs such as improved and good quality seeds, and affordable chemical fertilizers are also easily accessible compared to mid and far western region of Nepal. This partly justifies the increase in cereal production in the region although the country's food production has been stagnant over the past few decades.

The multiple comparisons of means showed that there is a significant difference in the average production of rice and maize during the past $30(\mathrm{p}<0.05)$ in all three districts as shown in table 2 . There was a significant difference in means of the average production of rice, maize and wheat during 2014 and 1984 for Solukhumbu district $(\mathrm{p}<0.05,0.01)$. Likewise, in Okhaldhunga, there was a significant difference in means between 2014 and $1984 / 1994$ for rice and maize $(\mathrm{p}<0.01)$. Furthermore, in Saptari district, there was a significant difference in means between 2014 and 2004, 1994, 1984 for rice and maize ( $\mathrm{p}<0.05)$.

Table 1. Trend of rate of production change of cereal crops during various years (negative (-) sign indicated the decreasing trend).

\begin{tabular}{lllll}
\hline Crops & Rate of change (\%) & Saptari & Okhaldhunga & Solukhumbu \\
\hline Rice & 10 years & -5 & -16 & -14 \\
& 20 years & 2 & -37 & -19 \\
& 30 years & 37 & 22 & 19 \\
\hline \multirow{2}{*}{ Maize } & 10 years & 31 & -28 & -38 \\
& 20 years & 51 & 77 & -45 \\
& 30 years & 60 & 78 & 3 \\
\hline \multirow{2}{*}{ Wheat } & 10 years & 48 & 30 & -37 \\
& 20 years & 75 & 68 & -33 \\
& 30 years & 95 & 71 & 50 \\
\hline
\end{tabular}


Table 2. Multiple Comparison of means (t/ha) between recent (2014) and 10 years before (2004), 20 years before (1994), 30 years before (1984).

\begin{tabular}{|c|c|c|c|}
\hline District & Crops & Years & Mean Difference \\
\hline \multirow[t]{9}{*}{ Saptari } & Rice & 10 & $959^{*}$ \\
\hline & & 20 & $1521 * *$ \\
\hline & & 30 & $2112 * *$ \\
\hline & Maize & 10 & $558 *$ \\
\hline & & 20 & $1057 * *$ \\
\hline & & 30 & $1307 * *$ \\
\hline & Wheat & 10 & 109 \\
\hline & & 20 & 125 \\
\hline & & 30 & 156 \\
\hline \multirow[t]{9}{*}{ Okhaldhunga } & Rice & 10 & 73 \\
\hline & & 20 & $359 * *$ \\
\hline & & 30 & $622 * *$ \\
\hline & Maize & 10 & -19 \\
\hline & & 20 & $210 * *$ \\
\hline & & 30 & $214 * *$ \\
\hline & Wheat & 10 & 20 \\
\hline & & 20 & 47 \\
\hline & & 30 & 49 \\
\hline \multirow[t]{9}{*}{ Solukhumbu } & Rice & 10 & 9 \\
\hline & & 20 & 152 \\
\hline & & 30 & $673 * *$ \\
\hline & Maize & 10 & -80 \\
\hline & & 20 & -61 \\
\hline & & 30 & $146^{*}$ \\
\hline & Wheat & 10 & -59 \\
\hline & & 20 & -34 \\
\hline & & 30 & $155^{* *}$ \\
\hline
\end{tabular}

Note. $*$ and $* *$ represents the significance at $95 \%$ and $99 \%$ level of confidence.

\subsubsection{Pest Infestation and Pesticide Use}

Farmers have reported pest infestation, which mostly occur during the summer season. Majority of the respondents (87\% of the total respondents of Saptari district, $71 \%$ of Okhaldhunga district and $90 \%$ of Solukhumbu district) indicated that pest attack is increasingly seen. Pest attack also occur during rainy season in Okhaldhunga and Solukhumbu district, and during winter season (9\% of the total respondents) in Saptari district. Furthermore, the majority of respondents reported the emergence of new types of pests (Figure 2), while some of the pests that existed before have now disappeared.

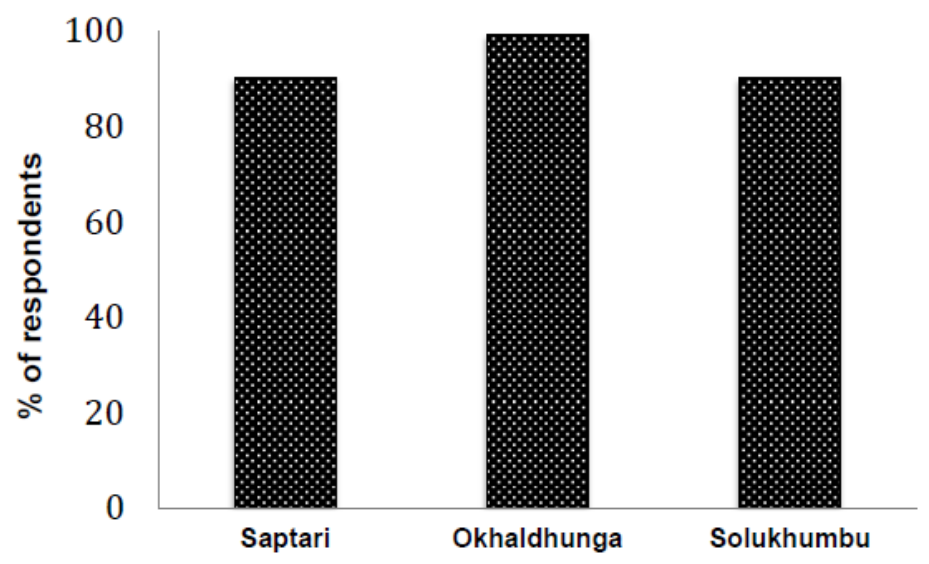

Figure 2. Emergence of new pests 
Incidences of pest infestations in the three study districts was reported to be increasing compared to 20 years ago for all crops, i.e., rice (97\% of the respondents in Saptari, $87 \%$ in Okhaldhunga, and $75 \%$ in Solukhumbu), maize (97\% of the respondents in Saptari, 91\% in Okhaldhunga, and 84\% in Solukhumbu), wheat (100\% of the respondents in Saptari, 76\% in Okhaldhunga, and 74\% in Solukhumbu) and vegetables (100\% of the respondents in Saptari, 88\% in Okhaldhunga, and $84 \%$ in Solukhumbu). Respondents from Solukhumbu (84\%) and Okhaldhunga districts (52\%) believed that the main reason for increase in pest attack is due to an increase in average temperatures, while respondents from Saptari district (73\%) felt that it was due to a decline in pest predators. The pests that are seen during summer season are also reported to infest crops during winter season. The majority of the respondents (96\%) of Saptari district use pesticides in their crops and vegetables, while the use is very low in Okhaldhunga and Solukhumbu districts (Figure 3).

Farmers in Saptari and Okhaldhunga district apply pesticides as per the prescribed dose(s) from the local agrovet stores, while in Solukhumbu, they apply the pesticides at random rates (Figure 4). The major pesticides used by farmers are: Niraculan, Carbine, Mirakulin, Monosil, Metacid, Thimet, Cypermethrin, Mancozeb, Zinc phosphate, and Adosil.

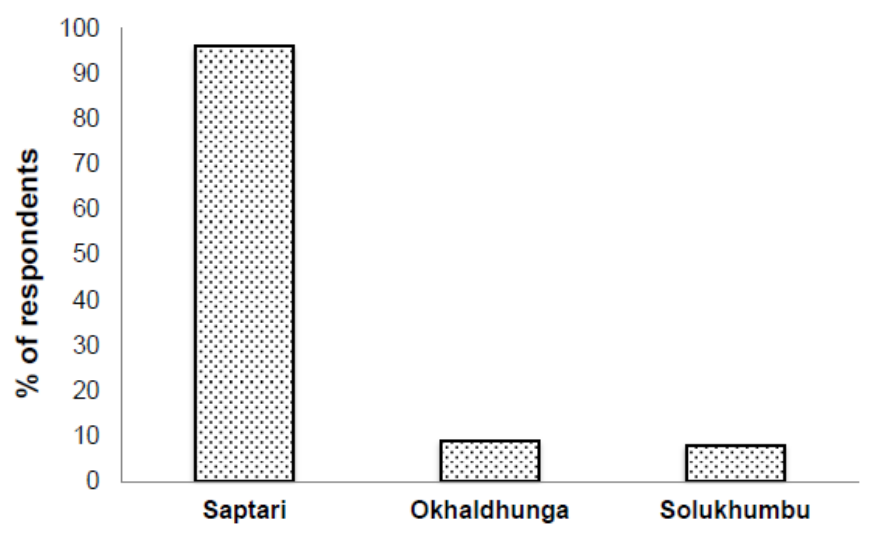

Figure 3. District-wise use of pesticides

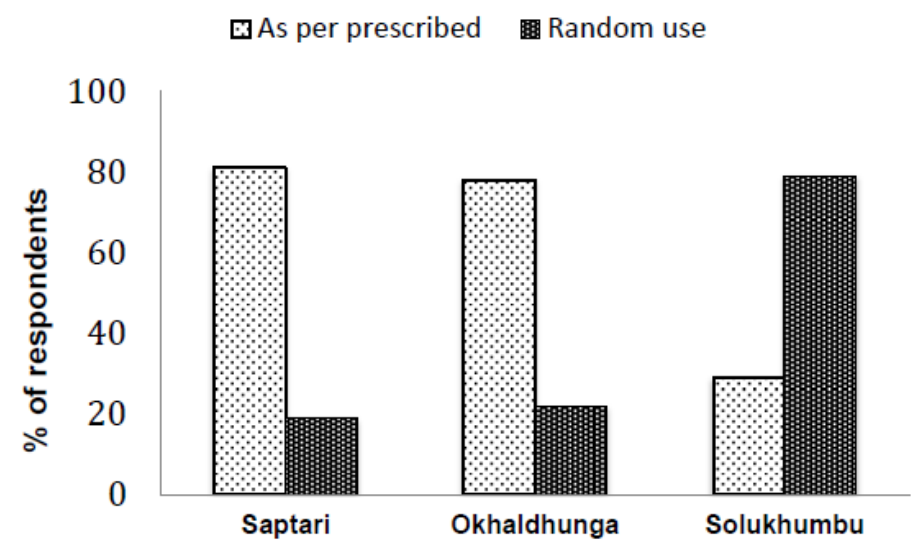

Figure 4. Pesticide application methods and rates

\subsection{Linkages between Climatic Variables and Crop Production}

Since the 1980s, average annual temperature and rainfall amounts for Saptari district is generally decreasing. However, the climatic data showed a negative correlation with the average production of rice, maize and wheat that has increased during the last 30 years. Such trend explains that farmers are managing to increase their production by adopting various practices. By contrast, in Okhaldhunga and Solukhumbu districts, the average production of rice, maize and wheat has shown a positive correlation with the climatic data. Thus, in the latter two districts, production has increased over the last 30 years with increasing trend of temperature and rainfall (Figure 5). 

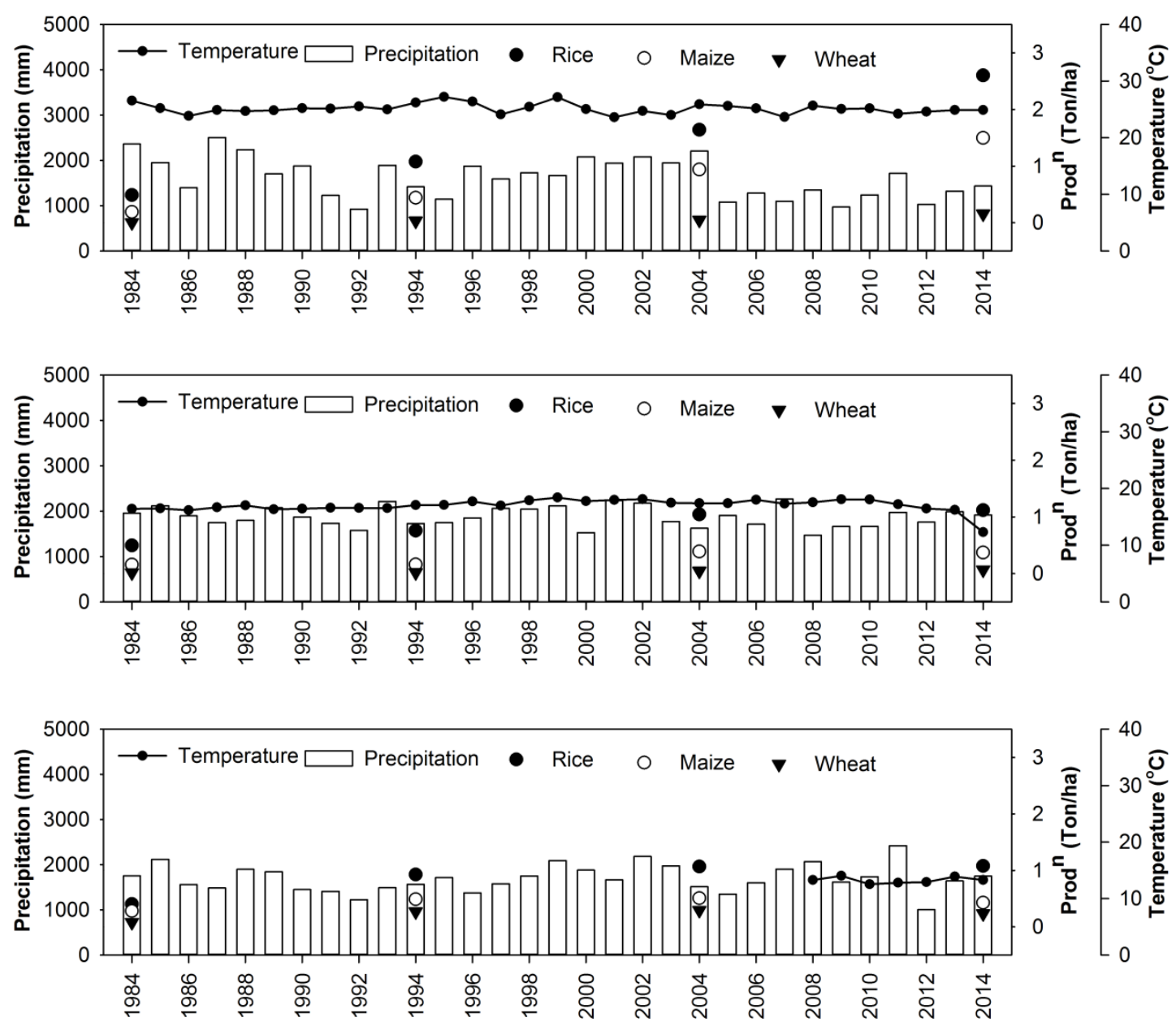

Figure 5. Linkages between climatic variables (temperature and precipitation) and crop productivity in three districts: a) Saptari b) Okhaldhunga and c) Solukhumbu

Farmers in Saptari district reported an increase in intense rainfall events, particularly during May to July, for the last 10-12 years, along with the late arrival of monsoon rains. Likewise, farmers in Okhaldhunga and Solukhumbu districts, who claimed they used to have monsoon by mid-June, also reported the arrival of monsoon to be typically delayed by about one month, with prolonged, partial and erratic rainfall events being more common. In general, farmers perceived the days to have become hotter. They have also reported more frequent incidences of drought. They claim that the events of frost have also decreased these days and fewer snowfall events occurred during the winter in the last three decades in Solukhumbu district.

In Saptari district, farmers have reported that the Koshi River has started significant damage since about 20 years ago, which has resulted in reduced overall productivity in the study area. Furthermore, the flood incidence in 2008 shifted the Koshi towards the west (present study area) that has further impacted the productive crop lands to this day. Farmers reported that the impacts of climatic variability have been felt on the quality of crops, overall productivity and also on crop biodiversity (fewer crop varieties being grown).

Farmers during focus group discussions and key informant interviews reported different adaptation measures they have adopted to minimize the impacts of climate change. These include re-plantation of trees and change in crop varieties such as cultivation of early maturing varieties, which ripen faster compared to the traditional varieties, so that they could plant and harvest within a shorter time. A few of the farmers were found to adopt the cultivation of rice varieties that can be grown at any time of the year, such as Hardinath. This variety can be harvested within a short duration and can be grown all year round. The survey also showed that high yielding varieties of rice are used mainly for two purposes: to increase the overall productivity and to combat the adverse climate change impacts on regular crops. For example, Mansuli, Kanchhi-mansuli, Makawanpur and Sita have been introduced coinciding with the use of chemical fertilizers and pesticides. Besides, adopting new varieties of 
crops, some farmers have also been practising occasional calendar shift to coincide with the late arrival of the monsoon for the last 10 to 12 years, particularly for rice cultivation. Planting, weeding and harvesting times have been delayed. Through the focus group discussions farmers expressed their interest to participate in community sensitization programs if offered through workshops and seminars, which could help in mitigating the impacts of climate change to some extent.

\section{Discussion}

The major concerns emerging on the pathway from traditional to commercial farming are associated mainly with crop varieties and agricultural inputs. Rice is the major cereal crop in Terai and hill regions; and maize in mountain region. The introduction of other cereal crop especially wheat seemed to be influenced by external intervention for example Asian Green Revolution (GR) and intensification (Dahal et al., 2009). In this study, we found that introduction of wheat was either as a drought resistant crop or as a crop that is used for religious purposes. While few other crops were found not cultivated in those areas due to the lack of manpower, market and economic benefit. In contrast, the adoption of various crops and use of agro-inputs in farming were influenced by infrastructural development together with adoption of GR in other studies (Brown and Shrestha, 2000; Brown and Kennedy, 2005; Raut et al., 2011; Raut et al., 2012). With introduction of higher yielding varieties of crops and vegetables, the traditional varieties of rice and maize are in process of disappearing with few of the varieties already non-existent from these regions. Farmers have reduced the cultivation of barley and buckwheat due to lack of manpower, and they have neglected and underutilized food crops (NUFCs). The NUFCs are important for ensuring sufficient supply of micronutrients to the human body, as their nutritional values are comparable to advanced cereal (rice, maize and wheat) (NNS, 2011; Adhikari et al., 2017). Thus, changing local food systems, food habits, existing policies and lack of nutritional knowledge, farmers have compromised food and nutritional security along with the traditional crops.

Although decreasing cereal production over the past 30 years correlated with the declining rainfall and temperature in Saptari district, overall production has increased. Farmers perceive that the major reasons of increase in production of cereal crops were due to the use of improved agricultural technology, use of high yielding varieties, use of pesticides and irrigation facility. Moreover, farmers have also noticed that the decreasing trend of crop production in some years, are not only due to the decrease in rainfall but also because of irregular rainfall pattern and pests infestation and diseases. Furthermore, farmers have reported the incidences of drought for declining yield for specified years. The declining crop production will have severe impact on overall food security (Poudel et al., 2017). Studies in South Asian context also reported significant negative impacts on crop productivity and food supply due to extreme events, especially floods and droughts (Chhetri et al., 2012; Bandara \& Cai, 2014). Although our study showed positive correlation between the crop yields and climatic data (temperature and rainfall) for hill (Okhaldhunga district) and mountain region (Solukhumbu district) of Nepal, the regional climate-model projections show temperature increases of $1.6^{\circ} \mathrm{C}-2{ }^{\circ} \mathrm{C}$ by $2030,2.3^{\circ} \mathrm{C}-2.9^{\circ} \mathrm{C}$ by 2050 , and $3.4^{\circ} \mathrm{C}-5.0^{\circ} \mathrm{C}$ by 2080 (Ahmed \& Suphachalasai, 2014). If, as expected, agricultural productivity is significantly affected, this could have severe negative impacts on the Nepalese economy, as agriculture is the mainstay of the country. Our finding is in accordance with those of Shumetie \& Alemayehu (2017). As stated by Shumetie \& Alemayehu (2017), rainfall inconsistencies and climatic variability are creating serious threat to smallholder households by impacting on overall agricultural productivity. Various modelling studies have already predicted and proved that Nepal is highly vulnerable to climate change, with agricultural productivity in Nepal likely to be severely affected by climate change (Joshi et al., 2011; Poudel \& Kotani, 2013; Chalise et al., 2015).

The major coping strategies that farmers have been following appeared to be changing the crop varieties and shifting the crop plantation season especially for rice. Similar adaptation measures have been known to practise at farm-level in a recent study by Kabir et al. (2017). Changes in cultivation practices such as water conservation methods, changes in sowing time and introduction of cash crops have already been reported (Poudel et al., 2017). In this study, the adaptation in agriculture are mainly autonomous and it implies that individuals or communities undertaking adaptation to climatic risk to agriculture independently of outside intervention. Another study by Joshi et al. (2017) also reported that the increased incidence of droughts during rainy season is one of the main factors for farmers' decision on adopting adaptation strategies.

\section{Conclusions}

Along the path from traditional to intensified agriculture, farmers have introduced high yielding varieties of crops and vegetables in the study areas, mainly because of enhanced production and increased returns. The cultivation of traditional varieties of rice and maize have vanished. Farmers have reduced the cultivation of 
barley and buckwheat due to lack of on-farm labour. The pest infestation mostly occurred during summer season and the pest attack is reported to be increasing since two decades, while few pests disappeared. The majority of farmers in hill and Terai regions use pesticides as per prescribed dose(s), while in mountain region, pesticide use is random. The production of rice and maize has significantly increased since three decades in Terai, hill and mountain region. The rainfall and temperature data showed negative correlation with the average production of rice, maize and wheat that has increased in Saptari district during the past 30 years. In contrast, in Okhaldhunga and Solukhumbu districts, the average production has increased with increasing temperature and rainfall. With changes in climate variables, farmers have adopted coping strategies mainly on crop varieties and crop plantation season. Conversely, limited access to climate resilient crop varieties and poor extension services, despite farmers' willingness to adopt adaptation measures, were the main barriers to climate change adaptation in the present context. Stronger agricultural research and support services, community-focused farming education and training are critically important for effective adaptation to climate change.

\section{Acknowledgments}

We acknowledge Nepal Academy of Science and Technology (NAST)/Asian Development Bank (TA 7984-NEP) and NORHED SUNREM-Himalaya for the support of the study. We are grateful to the inhabitants and participants of the study area for their cooperation and support during information and data collection process.

\section{References}

Adhikari, L., Hussain, A., \& Rasul, G. (2017). Tapping the potential of neglected and underutilized food crops for sustainable nutrition security in the mountains of Pakistan and Nepal. Sustainability, 9, 291. https://doi.org/10.3390/su9020291

Ahmed, M., \& Suphachalasai, S. (2014). Assessing the costs of climate change and adaptation in South Asia Retrieved from https://think-asia.org/handle/11540/46

APP. (1995). Agricultural Perspective Plan (Final Report). National Planning Commission, Agricultural Projects Service Centre, Kathmandu, Nepal.

Bajracharya, R. M., \& Sherchan, D. P. (2009). Fertility status and dynamics of soils in the Nepal Himalaya: a review and analysis, in: D. P. Lucero, J. E. Boggs (eds), Soil Fertility. Nova Science Publishers, Inc., New York, pp112-114.

Bandara, J. S., \& Cai, Y. (2014). The impact of climate change on food crop productivity, food prices and food security in South Asia. Economic Analysis and Policy, 44(4), 451-465. https://doi.org/10.1016/j.eap.2014.09.005

Bartlett, R., Bharati, L., Pant, D., Hosterman, H., \& McCornick, P. (2010). Climate change impacts and adaptation in Nepal. Working Paper 139. Colombo: International Water Management Institute (IWMI).

Brown, S., \& Kennedy, G. (2005). A case study of cash cropping in Nepal: Poverty alleviation or inequity? Agriculture and Human Values, 22, 105-116. https://doi.org/10.1007/s10460-004-7234-z

Brown, S., \& Shrestha, B. (2000). Market-Driven Land-Use Dynamics in the Middle Mountains of Nepal. Journal of Environmental Management, 59, 217-225. https://doi.org/10.1006/jema.2000.0355

CBS. (2003). Statistical Yearbook Nepal 2003, Central Bureau of Statistics, Kathmandu.

CBS. (2011). Nepal living standard survey 2010/2011: Statistical report vol. I and II. Kathmandu: Central Bureau of Statistics (CBS).

Chalise, S., Maraseni, T. N., \& Maroulis, J. (2015). Adapting to climate variability: the views of peasant farmers in Nepal. International Journal of Global Warming, 7(3), 380-394. https://doi.org/10.1504/IJGW.2015.069369

Chhetri, N., Chaudhary, P., Tiwari, P. R., \& Yadav, R. B. (2012). Institutional and technological innovation: understanding agricultural adaptation to climate change in Nepal. Applied Geography, 33, 142-150. https://doi.org/10.1016/j.apgeog.2011.10.006

Dahal, B. M., Nyborg, I., Sitaula, B. K., \& Bajracharya, R. M. (2009). Agricultural intensification: food insecurity to income security in a mid-hill watershed of Nepal. International journal of agricultural sustainability, 7(4), 249-260. https://doi.org/10.3763/ijas.2009.0436

Dahal, B. M., Sitaula, B. K., \& Bajracharya, R. M. (2008). Sustainable agricultural intensification for livelihood and food security in Nepal. Asian journal of water, environment and pollution, 5(2), 1-12.

DWIDP. (2014). Annual Disaster Review 2013, Series XXI. Department of Water Induced Disaster Prevention, Ministry of Irrigation, Government of Nepal. 
FAO. (2008). Food and Agriculture Organization. Production statistics. FAOSTAT domain. Rome (available at http://faostat.fao.org/).

Jat. M. L., Dagar, J. C., Sapkota, T. B., Yadvinder, S., Govaerts, B., Ridaura, S. L., Sagarawat, Y. S., Sharma, R. K., Tetarwal, J. P., Jat, R. K., Hobbs, H., \& Stirling, C. (2016). Chapter Three - Climate change and agriculture: adaptation strategies and mitigation opportunities for food security in South Asia and Latin America. Advances in Agronomy, 137, 127-235. https://doi.org/10.1016/bs.agron.2015.12.005

Joshi, B., Ji, W., Joshi, N.B. (2017). Farm households` perception on climate change and adaptation practices: A case from mountain district of Nepal. International Journal of Climate Change Strategies and Management, 9(4), 433-445. https://doi.org/10.1108/IJCCSM-07-2016-0099

Joshi, N. P., Maharjan, K. L., \& Piya, L. (2011). Effect of climate variables on yield of major food-crops in Nepal. Journal of Contemporary India Studies: Space Society, Hiroshima University, 1, 19-26.

Kabir, M. J., Alauddin, M., \& Crimp, S. (2017). Farm-level adaptation to climate change in Western Bangladesh: An analysis of adaptation dynamics, profitability and risks. Land Use Policy, 64, 212-224. https://doi.org/10.1016/j.landusepol.2017.02.026

Lal, R. (2011). Soil degradation and food security in South Asia.In: R. Lal et al. (eds), Climate change and food security in South Asia. Dordrecht, Heidelberg, New York and London: Springer. https://doi.org/10.1007/978-90-481-9516-9

MOE. (2010). National Adaptation Program of Action to CC. Ministry of Environment, Kathmandu. Nepal.

NNS-GoP. (2011). National Nutrition Survey. Planning Commission/Planning and Development Division. Islamabad, Pakistan.

Paudel, B., Acharya, B. S., Ghimire, R., Dahal, K. R., \& Bista, P. (2014). Adapting agriculture to climate change and variability in Chitwan: Long-term trends and farmers' perceptions. Agricultural Research, 3(2), 165-174. https://doi.org/10.1007/s40003-014-0103-0

Pingali, P. I., \& Rosegrant, M. W. (2001). Intensive food systems in Asia: Can the degradation be reversed? In Tradeoff or Synergies? Agricultural Intensification, Economic Development and the Environment, edited by D. R. Lee and C. B. Barrett, pp 383-398. Wallingford, UK. https://doi.org/10.1079/9780851994352.0383

Poudel, S., \& Kotani, K. (2013). Climatic impacts on crop yield and its variability in Nepal: do they vary across seasons and altitudes? Climate Change, 116(2), 327-355. https://doi.org/10.1007/s10584-012-0491-8

Poudel, S., Funakawa, S., \& Shinjo, H. (2017). Household perceptions about the impacts of climate change on food security in the mountainous region of Nepal. Sustainability, 9, 641. https://doi.org/10.3390/su9040641

Pyakuryal, B., Thapa, Y. B., \& Roy, D. (2005). Trade liberalization and food security in Nepal. Discussion Paper 88, Washington DC. International Food Policy Research Institute (IFPRI).

Raut, N., \& Sitaula, B. K. (2012). Assessment of fertilizer policy, farmers' perceptions and implications for future agricultural development in Nepal. Sustainable Agriculture Research, 1(2), 188-200. https://doi.org/10.5539/sar.v1n2p188

Raut, N., Sitaula, B. K. \& Aune, J. B., \& Bajracharya, R. M. (2011). Evolution and future direction of intensified agriculture in the central mid-Hills of Nepal. International Journal of Agricultural Sustainability, 9, 537-550. https://doi.org/10.1080/14735903.2011.609648

Regmi, B. R., \& Adhikari, A. (2007). Climate change and human development-risk and vulnerability in a warming world, Country case study-Nepal. Human Development Report.

Shumetie, A., \& Alemayehu, M. (2017) Effect of climate variability on crop income and indigenous adaptation strategies of households, International Journal of Climate Change Strategies and Management, 10(1), 121-141. https://doi.org/10.1108/IJCCSM-04-2016-0039

Tiwari, K. R., Rayamajhi, S., Pokharel, R. K., \& Balla, M. K. (2014). Determinants of the climate change adaptation in rural farming in Nepal Himalaya. International Journal of Multidisciplinary and Current Research, 2, 234-240.

\section{Copyrights}

Copyright for this article is retained by the author(s), with first publication rights granted to the journal.

This is an open-access article distributed under the terms and conditions of the Creative Commons Attribution license (http://creativecommons.org/licenses/by/3.0/). 